\title{
Anterior abdominal wall abscess secondary to spontaneous rupture of liver abscess in a resource-limited, rural, surgical setting: A case report
}

\section{Royson Dsouzaa, Mrudula Rao ${ }^{\mathrm{b}}$, Harshad Arvind Vanjare ${ }^{\mathrm{c}}$, Manbha Rymbaid}

a MBBS, MS, Consultant Surgeon, Ashwini Gudalur Adivasi Hospital, The Nilgiris, Tamil Nadu, India
b MBBS, PGDFM, Ashwini Gudalur Adivasi Hospital, The Nilgiris, Tamil Nadu, India
c MBBS, MD, Associate Professor, Department of Radiology, Christian Medical College and Hospital, Vellore,
India
${ }^{d}$ MBBS, MS, MCH, Department of Hepatobiliary Surgery, Christian Medical College and Hospital, Vellore, India

\begin{abstract}
Liver abscess continues to be a major surgical burden in low-and mid-low-income countries like India. Spontaneous rupture into the anterior abdominal wall is an uncommon presentation of pyogenic liver abscess. A 53-year-old diabetic female presented with acute pain in the right, upper quadrant of the abdomen. On examination, she had an anterior abdominal wall abscess with tender hepatomegaly. On further evaluation with ultrasonography and plain computed tomography, a diagnosis of liver abscess in the right lobe with rupture into the anterior abdominal wall was made. She was treated successfully in a tribal secondary care hospital with an ultrasound-guided aspiration followed by surgical drainage under local anesthesia. This case report highlights that a considerable number of patients with liver abscess and its complications can be appropriately managed in resource-limited, rural, surgical centers.
\end{abstract}

Key Words: liver abscess, spontaneous rupture, resource-limited setting, minimally invasive surgery, percutaneous drainage

\section{Introduction}

Liver abscess is one of the oldest surgical emergencies, described from the time of Hippocrates. ${ }^{1}$ Of the complications associated with it, rupture into the anterior abdominal wall is an unusual event and can lead to increased morbidity and mortality. ${ }^{2,3}$ Much has evolved in their management with lesser invasive procedures being the standard of care. Consequently, liver abscess, which was primarily a surgical condition, is now easily being managed by interventional radiologists. However, in a resource-limited, rural, surgical setting, most facilities are not properly equipped or available. Management of the patient still remains in the hands of a surgeon.

In this current report, we present a 53-yearold female who was diagnosed with a liver abscess which had ruptured into the anterior abdominal wall and was successfully managed with the available resources in a rural tribal health care facility. Her clinical details, relevant investigations, and challenges in management have been described along with a review of the literature. 
Consent was obtained from the patient for her case to be reported.

\section{Patient Information}

A 53-year-old female, a tea estate worker in the Nilgiris, Tamil Nadu, presented with a history of upper abdominal pain for 20 days. It was of insidious onset, a dull aching pain with no radiation or migration. Pain was not associated with the intake of food and was relieved with analgesics. There was no history of vomiting, altered bowel habit, jaundice, or loss of appetite. The patient had had high-grade fever with chills for the previous five days with progressive worsening of the pain. She was a known type 2 diabetic on oral hypoglycemic agents and had undergone laparoscopic cholecystectomy for symptomatic cholelithiasis eight years previously which was uneventful.

\section{Clinical Findings}

On examination, she was in acute distress due to pain. Her pulse rate was 90 per minute and blood pressure was 110/70 $\mathrm{mm}$ of $\mathrm{Hg}$. Her general physical examination was unremarkable. On abdominal examination, there was a swelling in the right hypochondrium measuring $3 \times 2 \mathrm{~cm}$ that was tender and had locally increased temperature. The swelling was confined to the parietal wall. The liver was enlarged $2 \mathrm{~cm}$ below the right subcostal margin and was tender on palpation. The rest of her abdominal examination was unremarkable.

\section{Diagnostic Assessment}

With a clinical suspicion of an anterior abdominal wall abscess, the patient underwent further evaluation. The relevant laboratory investigations are summarized in Table 1. To better characterize the lesion, ultrasonography (USG) of the abdomen was done that showed a hypoechoic mass in the liver with internal echoes and a parietal wall collection consistent with an abscess. Following this, a plain CT was done showing a subcapsular abscess involving the right lobe of the liver with partial rupture and extension into the anterior abdominal wall (Figure 1).

Table 1. Relevant laboratory investigations

\begin{tabular}{ll}
\hline Test & Result \\
\hline Complete blood count & Hemoglobin: $12.1 \mathrm{~g} / \mathrm{dL}$, Total WBC count: 11400 cells $/ \mathrm{mm}^{3}$, Differential count: \\
& Neutrophils- $68.6 \%$, Lymphocytes- $30.8 \%$, Monocytes-5.6\%, Platelets: 3.79 lacs $/ \mathrm{mm}^{3}$ \\
Creatinine & $1.0 \mathrm{mg} / \mathrm{dL}$ \\
Random blood sugar & $310 \mathrm{mg} / \mathrm{dL}$ \\
Liver function tests & SGPT: $8.5 \mathrm{IU} / \mathrm{L}$, SGOT: $12.5 \mathrm{IU} / \mathrm{L}$, Prothrombin time: $20 \mathrm{~s}$, INR: 1.3 \\
\hline
\end{tabular}

Figure 1. Non-contrast CT axial sections at the level of the liver demonstrating a well-defined cystic area in the right lobe of the liver in keeping with an abscess (black arrows) with focal rupture and extension into the anterior abdominal wall (white arrow)
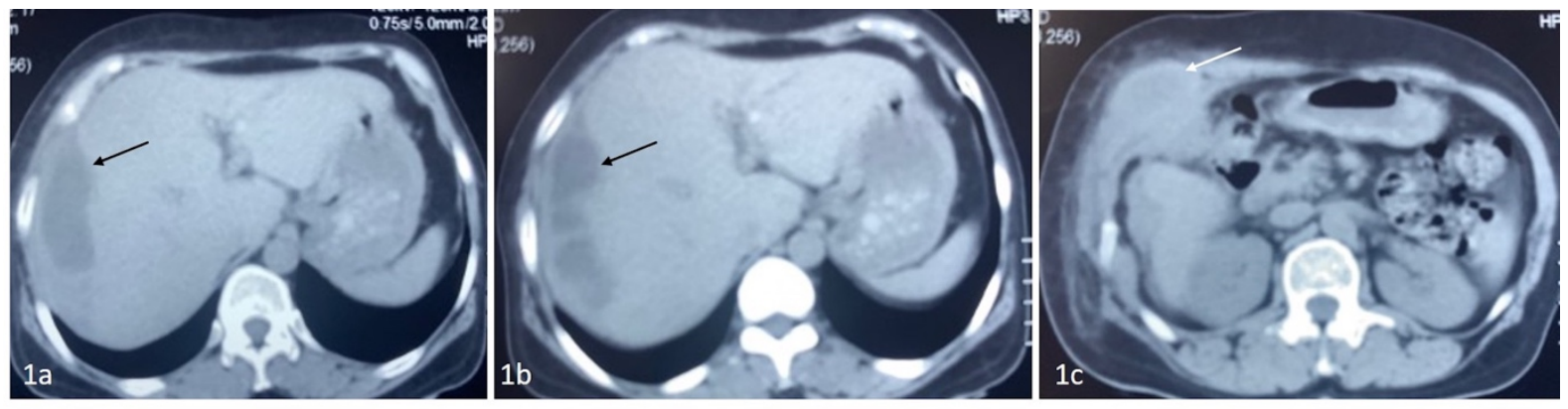

\section{Therapeutic Interventions}

The patient was started on broad-spectrum intravenous antibiotics (Piperacillin-Tazobactam
$4.5 \mathrm{~g}$ every 6 hours and Metronidazole $500 \mathrm{mg}$ every 8 hours), and drainage of the abscess was planned. As there was no evidence of intraperitoneal rupture of the abscess, a laparotomy 
was unnecessary. However, image-guided pigtail drainage was not possible in our setting due to a lack of resources and personnel. Hence, a USG guided aspiration was done to confirm the location of the abscess. Following this, a $3 \mathrm{~cm}$ skin incision was made under local anesthesia on the premarked site, and the abscess cavity was accessed. After draining the pus, a 16F Foley catheter was maneuvered into the abscess cavity to act as a drain. The wound was closed with widely placed interrupted sutures. The patient was stable after the procedure and recovered well after receiving 7 days of antibiotics. The culture from the pus grew Escherichia coli which was penicillin-sensitive. The patient was discharged on post-operative day 8 with the drain in situ and was discharged on oral antibiotics and Metronidazole for 4 weeks.

\section{Follow-up and Outcomes}

On follow-up, the patient was clinically well and afebrile. The wound was healthy, and the drain output serially decreased. USG after 21 days showed no residual abscess, and the drain was removed (Figure 2). On 5 months' follow-up, the patient was asymptomatic without evidence of recurrence of abscess.

Figure 2. Follow-up USG showing a resolution of the abscess

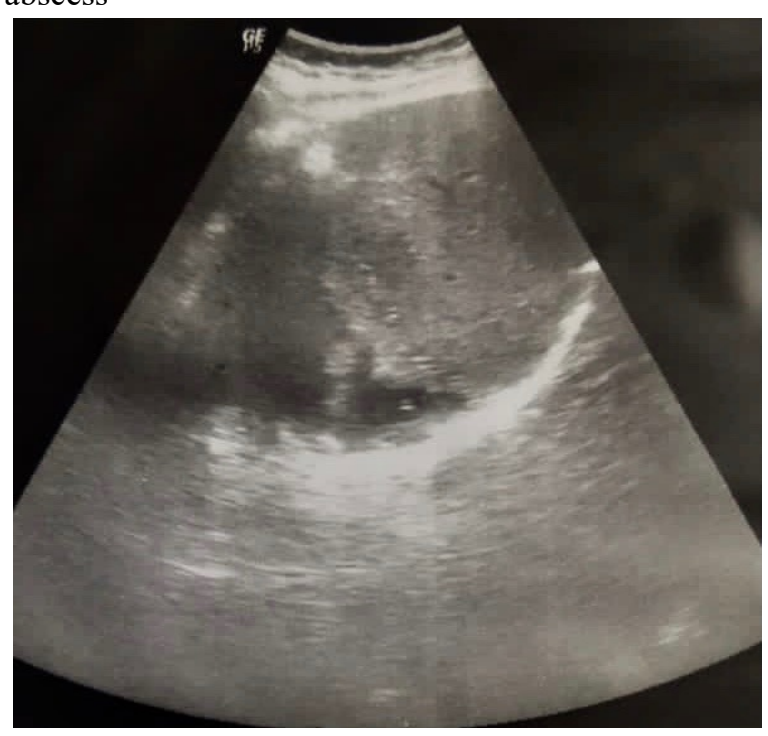

\section{Discussion}

Liver abscesses, both amoebic and pyogenic, continue to pose a major public health problem in tropical countries like India. ${ }^{4-6}$ Although there are no recent national or regional epidemiological studies to determine the prevalence of liver abscess in India, rural patients share a fair burden., ${ }^{4,6}$ The management of liver abscess has improved significantly over the years with the aid of better imaging modalities for early diagnosis and initiation of appropriate therapy. ${ }^{7-9}$ Similarly, the procedural morbidity has been reduced considerably due to the employment of lesser invasive modalities like percutaneous aspiration and percutaneous drainage techniques. . $^{5,10,11}$ Transperitoneal drainage via a laparotomy, traditionally the treatment of choice for drainage of liver abscess, has taken a back seat in the current era and is reserved only for certain complications. ${ }^{11,12}$ The successful management of a patient with liver abscess, however, depends predominantly on the available expertise and resources.

Distinguishing between pyogenic and amoebic abscesses is important as the management differs. Patients with pyogenic abscess are generally in the advanced age group and are immunosuppressed. Fever, chills, right upper quadrant pain, jaundice, weight loss, and nausea are the common manifestations. In contrast, patients with amoebic abscess tend to be young and can have a history of diarrhea in addition to abdominal pain and fever. ${ }^{7}$ In abscesses larger than $5 \mathrm{~cm}$ or $200 \mathrm{cc}$, drainage remains the cornerstone in treatment along with the initiation of appropriate antibiotics. ${ }^{13,14}$ Metronidazole is amoebicidal and the treatment of choice in amoebic abscess, with or without percutaneous aspiration. Pyogenic abscesses more frequently warrant a drainage procedure along with broadspectrum antibiotics and Metronidazole. In an ideal tertiary care setup, the majority of these patients are managed by interventional radiologists using USG or CT guided pigtail catheter placement. However, this is not easily made available in many rural surgical centers like ours where the management lies in the hands of a 
surgeon. Although our patient was sufficiently hemodynamically stable to be referred to a more ideal facility, due to the COVID-19 pandemic and travel restrictions, this was not possible. Moreover, like many other rural patients, our patient preferred to get treated at a hospital close to home. ${ }^{15}$

Ultrasonography is a valuable addition to a surgeon's diagnostic tools, especially in resource poor-settings. Surgeons can competently perform USG of the abdomen for focused assessment with sonography (FAST) in trauma, breast, thyroid, and vascular systems. ${ }^{16}$ The presence of a hypoechoic lesion with internal echoes and an irregular margin within the liver is characteristic of an abscess which can be easily diagnosed by a surgeon. ${ }^{7}$ Similarly, USG guided aspiration serves as an important diagnostic and therapeutic modality by confirming the presence of pus. We considered a CT scan after USG to rule out other smaller collections which could have been missed on USG. However, in retrospect, we feel that the CT scan was an unnecessary step as it did not aid in the ultimate management of the case. Hence, we do not consider the use of CT to be routinely necessary, especially when the USG is performed by an experienced sonologist.
Rupture of pyogenic liver abscess is a rare complication that can lead to increased morbidity and mortality. ${ }^{2}$ The other reports of abdominal wall abscess secondary to a pyogenic liver abscess are summarized in Table 2. The associated factors are postulated to be Klebsiella infection, diabetes mellitus, gas formation in the cavity, and involvement of the left lobe of the liver. ${ }^{17}$ Our patient was a diabetic but did not have any other associated features mentioned above. The previous laparoscopic cholecystectomy could have contributed to the pathway of spread as the abscess was close to the right hypochondrium port site. There is no consensus in the management of liver abscess ruptured into the abdominal wall. In general, this is considered a surgical emergency but the management largely depends on the site of rupture and condition of the patient. ${ }^{2,3,17,18}$ Following a USG-guided localization, we were able to successfully access the abscess cavity with a small skin incision using local anesthesia. Instead of a pigtail catheter, a foley catheter was used which is easily available in all rural surgical centers. There were no complications related to the drain such as infection, blockage, or displacement.

Table 2. Review of literature on rupture of liver abscess into the anterior abdominal wall

\begin{tabular}{|c|c|c|c|c|c|c|c|}
\hline Authors & Age & $\begin{array}{l}\text { Gen } \\
\text { der }\end{array}$ & Associated factor & $\begin{array}{l}\text { Liver } \\
\text { lobe }\end{array}$ & $\begin{array}{l}\text { Abdominal } \\
\text { region }\end{array}$ & Bacteria & Management \\
\hline $\begin{array}{l}\text { Kawosa } \\
\text { et al (19) }\end{array}$ & 31 & $\mathrm{~F}$ & $\begin{array}{l}\text { Previous laparotomy } \\
\text { for liver abscess }\end{array}$ & Right & $\begin{array}{l}\text { Right } \\
\text { hypochondrium }\end{array}$ & $\begin{array}{l}\text { Klebsiella } \\
\text { pneumoniae }\end{array}$ & $\begin{array}{l}\text { Percutaneous } \\
\text { drainage }\end{array}$ \\
\hline $\begin{array}{l}\text { Belabbes } \\
\text { et al }(20)\end{array}$ & 78 & $\mathrm{~F}$ & $\begin{array}{l}\text { Choledoco- } \\
\text { duodenostomy for } \\
\text { choldecolihtiasis }\end{array}$ & Left & Epigastrium & $\mathrm{N} / \mathrm{A}$ & $\begin{array}{l}\text { Percutaneous } \\
\text { drainage }\end{array}$ \\
\hline $\begin{array}{l}\text { Zizzo et } \\
\mathrm{al}(2)\end{array}$ & 95 & $\mathrm{~F}$ & $\mathrm{~N} / \mathrm{A}$ & Left & $\begin{array}{l}\text { Epigastrium and } \\
\text { umbilical region }\end{array}$ & $\begin{array}{l}\text { Proteus } \\
\text { mirabilis }\end{array}$ & $\begin{array}{l}\text { Antibiotics } \\
\text { only }\end{array}$ \\
\hline $\begin{array}{l}\text { Ndong et } \\
\text { al(21) }\end{array}$ & 6 & $\mathrm{~N} / \mathrm{A}$ & N/A & Left & $\begin{array}{l}\text { Right } \\
\text { hypochondrium }\end{array}$ & $\begin{array}{l}\text { Staphylococ } \\
\text { cus aureus }\end{array}$ & $\begin{array}{l}\text { Percutaneous } \\
\text { drainage }\end{array}$ \\
\hline $\begin{array}{l}\text { Gupta et } \\
\mathrm{al}(22)\end{array}$ & 35 & $\mathrm{~F}$ & Tuberculosis & Right & $\begin{array}{l}\text { Right } \\
\text { hypochondrium } \\
\text { and lower chest }\end{array}$ & $\begin{array}{l}\text { Mycobacteri } \\
\text { um } \\
\text { tuberculosis }\end{array}$ & $\begin{array}{l}\text { ATT and USG } \\
\text { guided } \\
\text { aspiration }\end{array}$ \\
\hline $\begin{array}{l}\text { Current } \\
\text { case }\end{array}$ & 53 & $\mathrm{~F}$ & $\begin{array}{l}\text { Diabetes, } \\
\text { Previous laparoscopic } \\
\text { cholecystectomy }\end{array}$ & Right & $\begin{array}{l}\text { Right } \\
\text { hypochondrium }\end{array}$ & E. coli & $\begin{array}{l}\text { Percutaneous } \\
\text { aspiration and } \\
\text { surgical } \\
\text { drainage }\end{array}$ \\
\hline
\end{tabular}

Notes: F: Female, N/A: not available.

Ultrasound-guided drain placement is a skill that can be easily acquired by a surgeon even in cases of liver abscess without rupture. This is crucial, especially in a resource-limited rural setting. Moreover, if there are procedural complications during or following the drain placement that necessitate surgical intervention, it can be handled competently by a surgeon. 


\section{Conclusion}

The management of liver abscess has evolved considerably with aid of interventional radiological techniques in drainage of the abscess. However, many subsets of these patients can be managed in resource-limited, rural, surgical centers using USG-guided localization and drainage. Spontaneous rupture of liver abscess into the anterior abdominal wall is a rare complication necessitating an early surgical intervention. The treatment consists of broadspectrum, intravenous antibiotics and drainage of the abscess depending on the location and the general condition of the patient.

\section{References}

1. Papavramidou N, Samara A, Christopoulou-Aletra H. Liver abscess in ancient Greek and GrecoRoman texts. Acta Medico-Hist Adriat AMHA. 2014;12(2):321-8.

2. Zizzo M, Zaghi C, Manenti A, Luppi D, Ugoletti L, Bonilauri S. Abdominal wall abscess secondary to spontaneous rupture of pyogenic liver abscess. Int J Surg Case Rep. 2016;25:110.

http://doi.org/10.1016/j.ijscr.2016.06.026

3. Chong VH, Zainal-Abidin Z, Hassan H, Chong CF. Rare complications of pyogenic liver abscess. Singapore Med J. 2010 Oct;51(10):e169-172.

4. Reddy P, Ashwin K, Srinivasan N, Halbhavi MR. A study of treatment outcomes of liver abscess in a rural tertiary care centre. Int Surg J. 2019 Jun 29;6(7):2439-43. http://doi.org//10.18203/23492902.isj 20192970

5. Manza J, Makwana H, Pancholi M, Verma N. Study of different modalities of management in patients with liver abscess in a tertiary care centre. 2018;6(1):5. http://doi.org/10.17354/liss/2018/115

6. Rickard J, Beilman G, Forrester J, Sawyer R, Stephen A, Weiser TG, et al. Surgical Infections in low- and middle-income countries: a global assessment of the burden and management needs. Surg Infect. 2019 Dec 9;21(6):478-94. http://doi.org/10.1089/sur.2019.142

7. Holzheimer RG, Mannick JA, editors. Surgical treatment: evidence-based and problem-oriented. Munich: Zuckschwerdt; 2001. PMID: 21028753.

8. Donovan AJ, Yellin AE, Ralls PW. Hepatic abscess. World J Surg. 1991 Apr;15(2):162-9. https://doi.org/10.1007/BF01659049
9. Runge VM, Wells JW, Williams NM. Hepatic abscesses. Magnetic resonance imaging findings using gadolinium-BOPTA. Invest Radiol. 1996 Dec;31(12):781-8.

https://doi.org/10.1097/00004424-199612000$\underline{00008}$

10. Kathel P, Mudgal MM, Kushwah N. Comparison of various techniques used in the management of liver abscess [Internet]. :5. Available from:

https://www.semanticscholar.org/paper/Comparison -of-Various-Techniques-Used-in-The-of-KathelMudgal/4e6a87ea91feb36b0f6ac9f1f38ad8ba4de4e 732

11.Pitt HA. Surgical management of hepatic abscesses. World J Surg. 1990 Aug;14(4):498-504. https://doi.org/10.1007/BF01658675

12. Alkofer B, Dufay C, Parienti JJ, Lepennec V, Dargere S, Chiche L. Are pyogenic liver abscesses still a surgical concern? A Western experience [Internet]. Vol. 2012, HPB Surgery. Hindawi; 2012 [cited 2021 Jan 22]. p. e316013. Available from: https://downloads.hindawi.com/archive/2012/31601 $\underline{\text { 3.pdf }}$

13. Satish Kumar R, Madhushankar L, Nataraj Naidu R, Ramalingeshwara K, Laxmikantha L, Amit Gupta $\mathrm{M}$, et al. Treatment strategies in liver abscess our experience. J Evol Med Dental Sci. 2013 Nov 11;2(45):8768-75. https://doi.org/10.14260/jemds/1522

14. Cai Y, Xiong X, Lu J, Cheng Y, Yang C, Lin Y, et al. Percutaneous needle aspiration versus catheter drainage in the management of liver abscess: a systematic review and meta-analysis. HPB. 2014 Oct $1 ; 17$. https://doi.org/10.1111/hpb.12332

15. Sun X, Meng H, Ye Z, Conner KO, Duan Z, Liu D. Factors associated with the choice of primary care facilities for initial treatment among rural and urban residents in Southwestern China. PLOS ONE. 2019 Feb 7;14(2):e0211984. https://doi.org/10.1371/journal.pone.0211984

16. G S Rozycki. Surgeon-performed ultrasound: its use in clinical practice. Ann Surg. 1998 Jul;228(1):1628. https://doi.org/10.1097/00000658-199807000$\underline{00004}$

17. Chung Hwan Jun, Jae Hyun Yoon, Jin Woo Wi, Seon Young Park, Lee WS, Jung SI,et al. Risk factors and clinical outcomes for spontaneous rupture of pyogenic liver abscess. J Dig Dis. 2015 Jan; 16(1): 31-6. http://doi.org/10.1111/1751$\underline{2980.12209}$

18. Motoyama T, Ogasawara S, Chiba T, Suzuki E, Yokota H, Haga Y, et al. Successful non-surgical 
treatment of ruptured pyogenic liver abscess. Intern Med Tokyo Jpn. 2013;52(23):2619-22.

https://doi.org/10.2169/internalmedicine.52.0980

19.Kawoosa NU, Bashir A, Rashid B. Spontaneous cutaneous rupture of a pyogenic liver abscess. Indian J Surg. 2010 Aug;72(4):339-42. https://doi.org/10.1007/s12262-010-0131-3

20. Belabbes S. Anterior abdominal wall abscess revealing a pyogenic liver abscess: a case report. Research 2014;1:1256. http://doi.org/10.13070/rs.en.1.1256
21. Ndong A, Tendeng J, Ndoye N, Dieye A, Diallo A, ElMansouri $\mathrm{M}$, et al. Liver abscess ruptured in the abdominal wall: a rare complication in a child. Surg Chron. 2019 Sep 1;24:162-3.

22.Gupta G, Nijhawan S, Katiyar P, Mathur A. Primary tubercular liver abscess rupture leading to parietal wall abscess: a rare disease with a rare complication. J Postgrad Med. 2011 Oct 1;57(4):350. https://doi.org/10.4103/0022$\underline{3859.90095}$

Peer Reviewed: Submitted 8 Feb 2021, accepted 23 March 2021, published 30 July 2021

Competing Interests: None declared.

Correspondence: Royson Dsouza, Ashwini Gudalur Adivasi Hospital, India. roy6dsouza@gmail.com

Cite this article as: Dsouza R, Rao M, Vanjare HA, Rymbai M. Anterior abdominal wall abscess secondary to spontaneous rupture of liver abscess in a resource-limited, rural, surgical setting: A case report. Christ J Glob Health. July 2021; 8(1):72-77. https://doi.org/10.15566/cjgh.v8i1.507

(C) Authors. This is an open-access article distributed under the terms of the Creative Commons Attribution License, which permits unrestricted use, distribution, and reproduction in any medium, provided the original author and source are properly cited. To view a copy of the license, visit http://creativecommons.org/licenses/by/4.0/ 